\title{
Büyük Frederik Döneminin Stratejik Yönetim Açısından Değerlendirilmesi
}

\author{
Evaluation of Frederich the Great Period in Terms of Strategic Management
}

\section{UĞUR KESKIN}

\section{Ö Z}

Bu makalede, 1740-1786 yılları arasında Prusya hükümdarlığı yapan Büyük Frederik'in yönetim anlayışı, teorik açıdan değerlendirilmektedir. Makalenin önermesiyle araştırma sorusundan yola çıkılarak literatür incelemesi yürütülmüştür. Stratejik yönetim kapsamına giren anlatımlara yer veren kaynaklara odaklanılarak, belirli çıkarsamalar yapılmıştır. Hem stratejik yönetim hem de Büyük Frederik dönemini ele alan kaynaklara bağlı olarak gerçekleştirilen incelemeler ekseninde değerlendirmelerde bulunulmuştur. Büyük Frederik’in yönetimsel deneyimlerine konu olan hususların sistemli bir biçimde betimlenmesine çalışılmıştır. Nitel araştırma kapsamında yer verilen yorumlayıcı fenomenoloji olarak ifade edilen anlayış benimsenerek Büyük Frederik'in yönetsel faaliyetleri, stratejik yönetim kavram ve teorileri esas alınarak değerlendirilmiştir. Uzun vadeli düşünme biçimini, kendi yönetsel anlayışına uyarladığı ve mekanik nitelikteki birtakım uygulamaları, kişisel yönetim yaklaşımına uyarladığına ilişkin bulgular analiz edilmiştir. Gelecek çalışma önerisi olarak ise yönetim biliminin farklı alt alanları ile Büyük Frederik'in yönetsel faaliyetlerini ilişkilendirilebilecek hususlara değinilmiştir.

Jel Sinıflaması: M10, M12, M19.

Anahtar Kelimeler: Büyük Frederik, Strateji, Stratejik Yönetim.

\section{A B S T R A C T}

In this article, the management understanding of Friedrich the Great, who ruled Prussia between 1740-1786, is evaluated theoretically. Based on the proposal of the article, a literature review was conducted based on the research question. Certain inferences have been made by focusing on the sources that include the narratives within the scope of strategic management. Evaluations were offered on the basis of the investigations carried out depending on the sources dealing with both strategic management and the period of Friedrich the Great. The issues that are subject to the managerial experiences of the Friedrich the Great have been tried to be described in a systematic way. By adopting the understanding expressed as interpretive phenomenology included in the qualitative research, the managerial activities of Friedrich the Great were evaluated on the basis of strategic management concepts and theories. The findings that he adapted his long-term thinking style to his own managerial understanding and some mechanical applications to his personal management approach were analyzed. As a future study proposal, the issues that can be associated with the different sub-fields of management science and the managerial activities of Friedrich the Great are mentioned.

Jel Classification: M10, M12, M19.

Keywords: Friedrich the Great, Strategy, Strategic Management.

\section{DOI: 10.47934/tife.10.02.02}

1. Prof. Dr., Anadolu Üniversitesi, İşletme Fakültesi, Eskişehir, Türkiye. ORCID: 0000-0003-2740-4120

\section{SORUMLU Yazar / CORRESPONDING AUTHOR}

Uğur Keskin,

Prof. Dr., Anadolu Üniversitesi, İşletme Fakültesi, Eskişehir, Türkiye.

E-mail: ugurkeskin@anadolu.edu.tr

\section{BAŞVURU/SUBMITTED: 09.05.2021 \\ REVIZYON TALEBI / \\ REVISION REQUESTED: \\ SON REvizYoN / \\ LAST REVISION : \\ KABUL/ACCEPTED: \\ 31.08 .2021}

Atıf / Citation: Keskin, U. (2021). Büyük Frederik Döneminin Stratejik Yönetim Açısından Değerlendirilmesi. Trakya Üniversitesi İktisadi ve İdari Bilimler Fakültesi e-Dergi, $10(2)$, 86-97, 


\section{Giriş}

Dilsel/anlamsal sanatlar, etkinliğin sonunda fiziksel bir nesne ortaya çıkaran diğer sanat türlerinden ayrılmaktadır. Sanatsal yetkinlik ürünü olan ve en erken dönem müzik yazımı kabul edilen besteler, doğrudan bir şiirin sözleri üzerine yazılan notalardan meydana getirilmiştir (Lacoste, 1986, s. 19, Aktaran Bozkurt, 2014, s. 19). Bu nedenle şiir, müzik ve hitabet/söylev sanatları, antik Yunan dönemi ile tarihlenebilecek hem yakınlaşma hem de rekabete dayalı bir gelişmeyi beraberinde getirmiştir (Gören, 2017: 15). Antik dönemlerden günümüze, sanat dalları arasındaki yakınlaşma ve geçişkenlik, çok daha yaygınlık kazanmıştır. Bu durum, şiirin diğer sanat dalları bağlamında üstlendiği işlevlerde kendini daha belirgin bir biçimde hissettirmeye başlamıştır. Örneğin okuyucularca beğeni kazanan şiirlerin, müzikal eserlerin sözleri olarak kullanılması sıklıkla karşılaşılan bir durum hâline gelmiştir. Bir diğer söyleyişle, "anlatı" kavramıyla ifadesini bulan söylemsel uğraşılar; şiir ve edebiyatın türlerini, hatta müziği de kapsayacak bir biçime dönüşmüş bulunmaktadır. Düşünce düzleminde gerçekleşen bu tür ilerlemeler, farklı niteliklere sahip alanlar arasındaki yakınlaşmaları mümkün kılmaktadır. Söz konusu durum ise benzerliklere dayalı olguları bilimsel çalışma alanlarına taşıyabilmenin yolunu açmaktadır. Bu sayede de tarih sahnesinde (bu makale özelinde Büyük Frederik döneminde) yürürlüğe konulmuş çeşitli yönetim uygulamaları, günümüz bilimsel yönetim alanlarıyla (bu makale özelinde stratejik yönetim alanıyla) ilişkilendirilebilmektedir.

1980'li yıllardan itibaren özellikle piyasa rekabetinin giderek artmaya başlaması, işletmelerin adeta birbirleriyle savaş meydanındaki gibi rekabet etmelerine yol açmıştır. Bu süreçte işletmeler; fiyat, tanıtım, araştırma-geliştirme, pazar elde etme, patent, lisans ve birçok konuda birbirlerine karşı rekabet üstünlüğü sağlayabilmek için stratejiler geliştirmek durumunda kalmışlardır (Kılıç, 2019: 101). Stratejik yönetim anlayışının gelişme kaydettiği bu yıllarda, piyasa koşullarındaki rekabet ortamı "savaş", harp tekniklerinin uygulanmasını ise "strateji" gibi metaforlarla işletme literatürüne uyarlanmaya başlamıştır. Zira metafora dayalı yaklaşım, gerçekliği belirli ölçülerde yansıtabilme olanağı sağlamaktadır. Stratejik yönetimin kurucularından olan Porter'ın, özünde endüstriyel iktisatçı olmasını, bu durumun çarpıcı bir örneği olarak kabul etmek gerekmektedir. Nitekim Porter, iktisatçılar arasında yıllardır bilinen ve uygulanmakta olan ülkeler arasındaki karşılaştırmaya dayalı analizleri işletmelere uyarlamıştır. Uyarlamasının sonucunda ise kendisinin bile beklemediği dünya çapındaki bir ilgiyle karşılaşmıştır. Netice itibariyle stratejik yönetimin öncü teorisyeni olan Porter da metafor ve analojilerden hareketle kendi kavramsal ve kuramsal yaklaşımını ortaya koymuştur.

Yukarıda ifade edilen Porter'ın uyarlamaya dayalı yaklaşımından yola çıkılarak, tarihsel kişiliklerin gerçekleştirmiş olduğu yönetim uygulamalarının, günümüz literatüründeki kavram ve kuramlarla izah edilebileceği ve metaforik anlatım ile gerçeklik arasında belirgin bir yakınsama sağlayabileceği kanaatine ulaşılabilmektedir. Edinilen söz konusu kanaat, bu makalenin amacına ulaşması bakımından yol gösterici bir yön taşımaktadır. Zira bu makale, Prusya hükümdarı Büyük Frederik'in benimsediği yönetim anlayışını, günümüzün kapsamlı bir literatürü haline gelmiş bulunan stratejik yönetim yaklaşımı bağlamında ele almayı amaçlanmaktadır.

Anlatıya dayalı her türlü eylem, kendi metaforik kullanımına olanak tanımaktadır. Dolayısıyla da olguları, çok anlamlı bir metaforlar ve simgeler çokluğu içerisinden gösterebilmektedir (Özlem, 2019: 17). Benzetmeye dayalı olması, metafor kullanımının öne çıkan bir niteliğini ifade etmektedir. Öte yandan, Yönetim ve Örgüt Teorilerinde Metafor adlı kitabın yazarı Morgan (1998: 14), "metafor" kavramını, "dünyayı kavrayışımıza sinen bir düşünme biçimi ve bir görme biçimi" şeklinde tanımlamaktadır. Bu yönüyle metafor, bilgi ve benzetmeye dayalı olarak belirli bir unsuru, başka bir unsura isnat ederek anlamlandırmaya dayanan bir akıl yürütmeyi ifade etmektedir. Analoji kullanımında ise belirli benzerliklerden yola çıkılarak çıkarsamalarda bulunmaya çalışılmaktadır. Örneğin mekanik hareket konusunda elde edilen ilkelerin analojik olarak optik alanına uyarlanması, antik çağda Heron 
tarafından gerçekleştirilmiştir (Topdemir, 2008: 67). Bütün bu anlatımlardan yola çıkılarak, metaforik ve analojik yaklaşım aracılığıyla, tarihsel kişiliklerin yönetimsel uygulamalarının, çağdaş bilimsel literatür ekseninde incelemeye konu edilebileceği sonucuna ulaşılmaktadır. Dolayısıyla, benzetmeye dayalı anlatımın sağladığı anlam zenginliğinden de yararlanmak suretiyle, tarihsel kişiliklerin icraatlarının (anakronizm hatasına düşmekten kaçınılması şartıyla), günümüz bakış açısıyla izah edilebilmesi mümkün hâle gelmektedir. Nitekim çıkarsamaya bağlı olarak edinilen kanaatler konusunda Büyük Frederik (2016: 81); benzerlik, mecaz ya da karşılaştırmanın "ispat" anlamına gelmediğini bizzat kendisi de ifade etmektedir.

Bütün yazınsal çalışmalar, dünyevi ve anlamsal (ideal, zihinsel, kavramsal) bir bileşim içermektedir (Glendinning, 2014: 70). Ifade edilen bu genelleme, makaleye uyarlandığında, dünyevi olarak yönetimsel faaliyetler yürüten Büyük Frederik'in söz konusu faaliyetlerinin anlamsal (ideal, zihinsel, kavramsal) karşılıklarının ortaya çıkarılabilmesi mümkün gözükmektedir. Dolayısıyla makale çalışması kapsamında erişilen kaynakların, Büyük Frederik dönemini, gerçeklik ile örtüşen bir nitelikte yansıttıkları varsayımını da kabul etmek gerekliliği kendiliğinde ortaya çıkmaktadır.

Stratejik yönetim yazınında Sun Tzu, dikkat çekici bir biçimde ön plana çıkmaktadır. "Batı felsefesi Platon'a düşülmüş dipnotlardan ibarettir" diyen Whitehead, strateji düşüncesinin ise Sun Tzu'ya dipnot olduğu çıkarsamasında bulunmaktadır (Akad, 2003: 133). Yirminci yüzyılın strateji yazarlarının, Clausewitz ve Napolyon gibi uygulayıcı rolü öne çıkanlardan kısıtlı düzeyde alıntı yapmalarına karşın, bunun çok daha fazlasının Sun Tzu'dan yapılıyor olması, bu çıkarsamanın ana kaynağını teşkil etmektedir. Oysa bu makalede, stratejik yönetim söz konusu edildiğinde, Sun Tzu ve Clausewitz gibi öncüller ile sınırlı yaklaşımların doğru olmadığı anlayışı benimsenmektedir. Büyük Frederik gibi kapsamlı icraatlar ortaya koyan şahsiyetlere de odaklanılabileceği görüşü öne sürülmektedir. Büyük Frederik'in yönetime konu olan icraatlarını özellikle de mekanik anlayışa dayalı düzenlemelerinin, stratejik yönetim kapsamında ele alınabilmesi olası gözükmektedir.

Stratejik yönetim alanındaki çalışmaların çoğunlukla işletme yönetimi bağlamındaki içsel ve dışsal süreçlere dönük olarak yürütülmekte olduğu, bilinen bir gerçekliktir. Güncel içerikli teorik ve uygulamalı bu tür çalışmaların yanı sıra, stratejik yönetim anlayışının düşünsel kökenine ilişkin ve çoğunlukla Sun Tzu (Karabulut ve Değer, 2015; Wei, 2017; Waldron ve Huang, 2018; Wilson, 2018) ve Clausewitz (King, 1977; Oetinger ve diğ., 2002; Karaosmanoğlu, 2007; Gülboy, 2015) gibi öncül düşünürlerin ele alındığı, kuşkuya yer vermeyecek biçimde açıkça görülebilmektedir. Oysa Büyük Frederik gibi uygulayıcıları, stratejik yönetim yönüyle ele alan çalışmaların oldukça sınırlı olduğu görülebilmektedir. Çünkü Büyük Frederik ile ilgili çalışmaların çoğunlukla biyografi (Schieder, 2000), siyasi tarih (Dorn, 1931; Ritter, 1974; Carlyle, 1990), yürüttüğü savaşlar (Duffy, 1985; Showalter, 1996) gibi konularda kaleme alındığı, stratejik yönetim alanının ise dolaylı da olsa çalışmalara konu edilmediği görülebilmektedir. Özellikle Türkçe kaynaklarda, ilgili anahtar kelimelerle yapılan taramalarda, geçmiş dönemli çalışmalara rastlanamamaktadır. Stratejik yönetim literatürünün, pozisyon ekolü ve kaynaklara dayalı ekol gibi işletme yönetimi kapsamındaki görüşleri daha fazla bir biçimde ele alıyor olma durumu ise, bu makale ve benzer türden çalışmaların, ana akım çalışmalar içinde yer almasını güçleştiren bir unsur olarak dikkat çekmektedir.

\section{2. Çalışmanın Yöntemi}

Üzerinde genel bir mutabakat bulunan tarihsel kaynakların; olguları, gerçeklik ile çelişmeyen biçimde ortaya koyduğu varsayımına dayanarak aşağıdaki önermeyi ileri sürmek mümkün olabilmektedir: "Temsil ve benzerliklerden yararlanıldığı ve günümüz bilimsel teorilerine dayanıldığı takdirde, geçmiş yüzyıllardaki yönetsel uygulamalara ilişkin gerçekliklerin anlaşılması sağlanabilmektedir."

Yukarıdaki önermeye göre, stratejik yönetim yazınındaki kavramsal ve teorik izahlar, benzerlikler ya da metaforlar sayesinde anlaşılabilir kılınabilmektedir. Özellikle üst yönetim kademelerinde yer alan kişilerin yönetimsel çalışmaları, geçmiş dönemin gerçekliklerini günümüze yansıtabilmektedir. Ortaya 
koydukları geliştirici çabalar sayesinde isimlerini yüzyıllar sonrasına taşıyabilen bu (örnek düzeyde uygulama örnekleri ortaya koyan) yöneticiler (hükümdar ye da devlet adamları), kendi toplumlarına ve gelecek nesillere değerli katkılar sağlamışlardır.

Makalenin önermesinden yola çıkılarak şu araştırma sorusu yanıtlanmaya çalışılmaktadır: "Büyük Frederik'in gerçekleştirdiği yönetsel faaliyetler, zamanının ötesine geçerek çağdaş yönetim alanına anlamlı katkılar sağlayabilecek uygulamaları barındırmakta mıdır?"

Makalede, kaynak taraması üzerinde teorik tartışma yaklaşımı benimsenmiştir. Benimsenen bu yaklaşım, yönetim uygulamalarının ne tür bir payandaya dayanılarak yürütüldüğünün belirlenmesini (stratejik yönetimin hangi açıklayıcı mekanizması ile açıklanabileceğinin tespit edilmesini) sağlayabilmektedir.

Yukarıda ifade edilen varsayım, önerme ve araştırma sorusuna dayanarak çeşitli yorum ve değerlendirmelere yer verilen bu makale, fenomenolojik bir nitelik taşımaktadır. Ahlak Metafiziğini Temellendirme başlıklı eserinde Kant (2015: 301), nedensellikle donatılmış bir düşünce varlığı (aktör) konumundaki insanın, fenomen (gerçekten olduğu gibi) olarak algılanabileceğini çünkü söz konusu niteliği sayesinde, belirleyici nedenlerle ilişki içine girebildiğini vurgulamaktadır. Kant'ın ifadelerine göre her bir bireyi fenomen olarak kabul edebilmek olası görünmekle birlikte, Creswell'e (2016: 77) göre fenomenolojik çalışma, üzerinde durulan kişi veya grubun, belirli bir fenomen ya da kavrama dair deneyimlenen yaşantılar neticesinde meydana gelen anlamı ifade etmektedir. Makale, yukarıda ifade edilen hususlar dikkate alınarak, yorumlayıcı fenomenoloji türüne uygun olarak desenlenmiştir.

\section{Kavramsal Çerçeve}

Strateji, kelime kökeni olarak Eski Yunanca "stratos" (ordu) ve "ago" (yönetmek, yön vermek) kelimelerinin birleştirilmesinden oluşmaktadır (Yılmaz, 2009: 161). Generallik veya askerlik sanatı anlamına karşılık gelecek şekilde kullanılan bu kavrama, özellikle son yıllarda ilave ve farklı anlamlar da yüklenmeye başlanmıştır.

Stratejik yönetim kavramına bakıldığında, klasik anlamdaki "yönetim" tanımında ihmal edilen "uzun dönem" perspektifinin, bu tanıma eklemlendirilerek anlamlı bir katkı sağlandığı görülebilmektedir. Uzun vadeli düşünürken, yakın vade içinde gerçekleşecek olan ya da örgütün hâlihazırda yürümekte olan işleyişinden de uzaklaşılmaması gerektiği vurgulanmaktadır. Dünyanın ilk filozofu olarak kabul edilen ve aynı zamanda astronom olan Thales'in, gök cisimlerini incelerken, önündeki çukuru göremeyip yere düşmesi, etrafındaki insanların kinayeli sözlerine neden olmuştur. Thales'e ilişkin anlatıdan hareketle, uzun vadeli stratejik yönetim anlayışı benimsenirken, yakın vadeli işleyişin de aksatılmaması gerektiği çıkarsamasına ulaşılmaktadır. Stratejik yönetim anlayışında, örgütsel süreçler, iç ve dış şartlara uygun olarak, ulaşılmak istenilen hedeflerin gerekli bazı durumlarda revize edilerek düzenlenmesini gerekli kılmaktadır. Bir diğer deyişle, örgütün içinde bulunduğu gerçeklikler ile çelişmeyecek şekilde uyumcu davranma zarureti hiçbir zaman ortadan kalkmamaktadır. Nitekim Büyük Frederik (2016: 113), bu hususta “iki Yüzlü Janus” örneğini vererek dikkatli olunması gerektiğini vurgulamaktadır. Bilindiği üzere Roma mitolojisindeki kapı tanrısı olan Janus, biri öne biri arkaya bakan iki farklı yüze sahip bulunmaktadır. Genç yüzü ileriye (geleceğe), yaşlı yüzü ise geriye (geçmişe) bakmaktadır. Dolayısıyla bu benzetme, olguların iki farklı yönünü temsil etmekte, uzak geleceğe yönelmenin, geçmiş ya da yakın gelecek açısından zafiyete yol açmaması gereğini vurgulamaktadır.

Stratejik yönetim, 1975 yılı sonrasında bilimsel literatürde yer edinmeye başlamış olmasına karşın, düşünsel temel olarak Sun Tzu (1996) tarafından milattan önce beşinci yüzyılda yazılan Savaş Sanatı adlı esere dayanmaktadır. On altıncı yüzyıl Japon düşünürü Miyamoto Musashi'nin (2015) Beş Çember Kitabı ve on dokuzuncu yüzyıl düşünürlerinden Carl von Clausewitz'in (1999) Savaş Üzerine adlı eserleri de strateji düşüncesinin gelişimine katkı sağlamışlardır. Bu eserler kadar kapsamlı olmasa da tarih 
sürecinde pek çok filozof, strateji düşüncesi açısından değer ifade eden görüş öne sürmüştür. Fakat yukarıda sıralanan düşünürler kadar kapsamlı görüş ortaya koyan olmamıştır. Örneğin üçüncü yüzyıl filozofu Plotinos (2021: 69); ufki bakış, gelecek yönelimli olma, uzun erimli düşünme bağlamında görüşler ortaya koymakla birlikte bunu kapsamlı bir biçimde ele almamıştır.

Günümüzün çağdaş stratejik yönetim literatürü, yönetim bilimi konuları içinde kendi rüştünü ispat etmiş ve kendine has kavramları ile teorik zeminini oluşturmuştur. Kavramsal düzeyde ilk olarak 1975'te Ansoff tarafından kullanılan stratejik yönetim, takip eden yıllarda sürekli bir biçimde gelişim göstererek müstakil bir çalışma alanı niteliği kazanmaya başlamıştır. Ansoff öncesinde, askeri alanda ve savaşlarda kullanılan strateji kavramı, özellikle 1980'li yıllardan itibaren Porter öncülüğündeki “Pozisyon Ekolü" anlayışı doğrultusunda gelişim kaydetmiştir. 1990'lı yıllardan itibaren ise Hamel ve Prahalad öncülüğündeki "Kaynaklara Dayalı Ekol” kapsamındaki çalışmalar belirmeye başlamıştır. Stratejik yönetim literatürü elbette ki bu iki ekol ile sınırlı kalmamış, pek çok kavram, analiz ve izah biçiminin geliştirildiği bir alan olarak gelişimini günümüze kadar sürdürmeye devam etmiştir. Pozisyon Ekolü, iradeci bir anlayışı temsil etmektedir. Bu ekole göre yöneticilerin, sahip oldukları dönüştürücü nitelikler sayesinde, örgütsel sınırların dışında yer alan piyasa koşullarının (örgütün etki ve ilgi alanına giren tüm alanları) da etkinlikle yönetebilmesi mümkündür. Kaynaklara Dayalı Ekol ise asıl dikkatin, örgütün içsel süreçlerine yöneltilmesi gerektiğini öne sürmekte ve bu süreçleri geliştirici yöntemler üzerine yoğunlaşmaktadır.

\title{
4. İnceleme: Büyük Frederik Dönemi Yönetsel Uygulamalarının Stratejik Yönetim Açısından Değerlendirilmesi
}

Hegel'den (2011a: 37-38) yapılan aşağıdaki alıntı, Büyük Frederik'in yönetsel anlayışının, bu makale kapsamında ele alınmasının nedenini anlaşılır bir biçimde açıklamaktadır:

\begin{abstract}
Bunlar tarihteki büyük insanlardır ki... onlara kahramanlar denir... ereklerini ve görevlerini iç tinden türetmişlerdir ki, dış dünyaya bir kabuk gibi vurarak onu kırar... ve eylemleri öyle bir durum ve dünya yaratmıştır ki, yalnızca onların davası ve onların işi olarak görünür... zorunlu olanın ve zamanı gelenin bir iç görüsünü taşımışlardır. Davaları bu evrenseli, dünyalarının bir sonraki zorunlu aşamasını bilmek, bunu erekleri yapmak ve enerjilerini ona yöneltmek olmuştur... eylemleri ve söylemleri zamanın en iyisidir... durumu en iyi anlayan onlar olmuştur; aslında başka herkes onlardan öğrenmiş, yaptıklarını iyi ya da en azından uygun bulmuşlardır.
\end{abstract}

Fenomenolojik çalışma aracılığıyla, odak noktasına alınan fenomene ilişkin çıkarsamaların, genel geçer bir izah biçimine kavuşturulması hedeflenmektedir. Aşağıdaki aktarım, hem fenomenolojik yöntemi açıklarken, aynı zamanda Büyük Frederik'i de örnek göstermesi bakımından dikkat çekici bir nitelik taşımaktadır.

Maddenin bir düşünce ile kavranmasına herkes ulaşabilir. Ama karmaşık insan tiplerini, bir Wallenstein'ı, bir Richelieu'yü, bir Büyük Frederik'i anlamak çok azlarına vergidir. Sıradan ruhsal kategorilerle düşünmeye alışmış olanlar, onlara yaklaşamaz; hatta büyük bir tarihçinin önceden düşünmüş olduğu bir yerde bile. Fenomenolojik yönteme dayanan bilimler, anlamaya dayanan "geist" bilimlerden daha yüksek ölçüde aristokrat yapıdadır... Fenomenolojik yöntemdeki bu aristokrat nitelik, onun kullanılmasının güç olması anlamına gelir, ama onun doğruluğuna karşı bir kuşkuya neden olmaz (Geiger, 2015: 124).

Aşağıdaki alt başlıklar; yan olaylara, gölge olaylara gitmeden doğrudan fenomeni, bir değer deyişle asıl olguyu (Büyük Frederik'e ilişkin temel izlekleri) belirgin kılacak şekilde oluşturulmuştur (Rifat, 2020: 83). Dolayısıyla, aşağıdaki alt başlıktan itibaren, Büyük Frederik'in, yönetsel faaliyetlerinin stratejik yönetim ekseninde değerlendirildiği aktarım, anlatım ve değerlendirmelere yer verilmiştir. Büyük Frederik'i ve onun yürüttüğü faaliyetleri nakleden kaynak eserlerdeki anlatımların, uçlara kayma eğilimi göstermediği ve aşırı yorum içermediği varsayılarak söz konusu incelemeler yürütülmüştür.

\subsection{Uzun Vadeli Düşünmenin Yönetim Anlayışına Uyarlanması}


Hegel'in yukarıdaki anlatımları, "Stratejik Yönetim" kavramının (doğal olarak) anılmadığı fakat bu anlayışın ayırt edici nitelikleri arasında yer alan uzun vadeli bakış açısını etrafı bir biçimde ele almaktadır. Hegel'in yukarıda aktarılan ifadeleri ile uyum içindeki tarihsel bir şahsiyet olarak Büyük Frederik, stratejik yönetim literatüründeki diğer birçok kavram ile de örtüşen yönetsel faaliyetler yürütmüştür.

Hegel'e (2011a: 10) göre Almanya'da "parlak kafalar" olarak nitelendirilebilecek ustalar seyrek görülmektedir. Büyük Frederik ise bu bakımdan ünlü bir kuraldışıdır. "Böyle insanlar, hiç kuşkusuz yükseklerde duruyor olmalıdırlar. Ancak yukarıda durulduğu zaman olgular doğru olarak gözlenebilir ve her şey görünebilir, aşağıda küçük bir delikten dışarıyı seyrederken değil."

Yüksek katlı bir apartmanın en üst alt katındaki kişinin, alt katlarda yer alan diğerlerine göre çok daha geniş bir bakış açısına sahip olduğu genellemesini yapabilmek mümkündür. Hegel'in, "parlak kafalar" olarak nitelendirdiği insanlar da bulundukları üst seviyeye bağlı olarak geniş/engin bakış açılarına, ileriyi görme ufkuna, yine benzer bir anlama gelen gelecek projeksiyonuna sahip olmaktadırlar. Bu tür nitelikler, stratejik yönetimdeki uzun vadeye yönelimlilik ve ufki bakışa sahip olma şekilde de ifade edilebilecek yönler barındırmaktadır.

Büyük Frederik, edimsel devlet çıkarlarına evrenselliklerini ve en yüksek aklanmalarını kazandıran yeni çığırın onunla edimsellik kazandığı egemen olarak adlandırılabilir. Büyük Frederik özellikle devletin evrensel ereğini düşünce yoluyla kavramış olmakla ve egemenler arasında devletin evrenseline sıkı sıkıya sarılan ve tikeli, eğer devletin evrenseli karşı ise bundan böyle geçerli saymayan ilk egemen olmakla öne çıkar... Nasıl bir aile babası evdekilerin ve ona bağlı olanların iyiliği için çalışıp çabalayarak onlara bakar ve onları yönetirse, Frederik de öyle yaptı ve bunun benzersiz bir örneğini verdi (Hegel, 2011b: 108).

Hegel tarafından ifade edilen Büyük Frederik'e ilişkin yukarıdaki aktarım, olaylara bütüncül ve kapsamlı bir biçimde yaklaşma anlayışına işaret etmektedir. Büyük Frederik, kısa vadeli amaçlara yönelmeyip, devletin evrensel nitelikli ve uzun vadede çok daha kazanım sağlayıcı faaliyetlere öncelik vermiştir. Tümel (külli, geneli ilgilendiren) hususları, tikel (kısmi) hususlara her zaman üstün tutarak, yönetmiş olduğu devletin evrenseline sıkı bir biçimde bağlılık göstermiş, bu anlayışından, uzun süren hükümdarlı̆̆ı süresince ödün vermemiş, tutarlılık sergilemiştir.

Alman filozof Dilthey, Alman Ruh Tarihine Dair Tetkikler adlı kitabında Büyük Frederik'e özel bir değer atfetmektedir. Kitabın "Büyük Frederik ve Aman Tenvir Hareketi” başlıklı bölümünde Alman aydınlanmasına Büyük Frederik'in katkıları ele alınmaktadır. Dilthey'e (2004: 89) göre Büyük Frederik; pozitif felsefeye, ahlaki şuuru tercih etmektedir. Bunu da şu sözleriyle dile getirmektedir: "Ben ahlakı çok tercih ederim. İyi ahlak, cemiyet için, Newton'un bütün hesaplarından daha yüksek bir kıymeti haizdir." Ayrıca Büyük Frederik, İngiliz ve Fransız fikirlerinin Alman felsefesine girmesini mümkün kılan kişi olmuştur. Din ve kültür felsefesinde hoşgörüyü, hükümranlığı süresince gerçekleştirmeye çalışmıştır (Störig, 2013: 360-361). Nitekim Kant (2015: 318), Büyük Frederik'in bu yöndeki çabalarının hakkını teslim etmiş ve içinde yaşadığı çağı "Frederik'in yüzyılı" olarak nitelendirmiştir. Sıralanan bütün bu yaklaşımları göz önünde bulundurulduğunda Büyük Frederik'in önemli bazı konularda değer temelli bir anlayış oryaya koyarak, kaynaklara dayalı ekol görüşüne yakınsamakta olduğu görülebilmektedir. Bir diğer deyişle, ağırlıklı olarak mekanik anlayışa dayalı görünmesine karşın, değer eksenli anlayışı tümüyle yok saydığını ifade etmek tam anlamıyla doğru olmamaktadır.

Büyük Frederik, yurt içinde devlet şuurunu tesis etmeye çalışırken, geniş topraklara sahip, tüm dünyada hürmet gören bir devlet inşa etme emeli gütmüştür. Bu amacı gerçekleştirmeyi, bir krallık vazifesi olarak kabul etmiştir (Dilthey, 2004: 81). Sıkı bir tutumlulukla ve sürekli bir çabayla topraklarını yalnız savunmaya değil, aynı zamanda genişlemeyi sağlayacak güçlü bir teşkilatlanma yapısı oluşturmuştur. Nitekim öldügün̈de, arkasında Avrupa'nın büyük güçlerinden birini bırakmıştır (McNeill, 2005: 558). Büyük 
Frederik'in, kapsamlı görüşlere ve vizyona sahip olması, bunu da uzun vadeli amacından vazgeçmeksizin uygulama çabası içinde bulunması, stratejik yönetimin temel anlayışıyla belirgin bir koşutluk ortaya koymaktadır.

Savaş alanlarının görkemli kumandanı olan Büyük Frederik, sivil yönetimleri güçlendirmeye çalışmıştır. İmmanuel Kant'ı destekleyen Büyük Frederik, Prusya ruhunun ve kimliğinin en önde gelen örneğini teşkil etmektedir (Tuğcu, 2011: 16). Büyük Frederik, yaşadığı dönemin bilimsel olarak en ileri anlayışlarına sahip Endülüs ve Sicilya'daki Arap egemenliğinin nimetlerinden yararlanmıştır. Eğitimini de kuşkusuz bu etkilere borçluydu. Hatta o zamana kadar işitilmemiş bir girişimde bulunarak, Arap sultanıyla barışçı bir ilişki kurmuştur. Gerek bu davranışı, gerekse kiliseye aykırı düşünme ve yaşama tarzı onu dar görüşlü çağdaşları arasında olumsuz bir üne kavuşturmuş, sonunda Papa'nın lanetine bile uğramıştır (Bebel, 2019: 87). Büyük Fredrik'in; zamanının ilerisinde düşünme gücü, uzak erimli olma gibi nitelikleri, hem bu paragraftaki anlatımlarda hem de benzer hususlara değinilen aşağıdaki paragrafta da açıkça görülebilmektedir.

Büyük Frederik, sanata ve düşünceye önem vermiş, döneminin önde gelen filozof ve sanatçılarına yakın bir ilgi göstermiştir. Kendisine benzer bir anlayışa sahip olan Milattan Önce beşinci yüzyıl Antik Yunan devlet adamı Perikles'e ilişkin şunları dile getirmektedir (Büyük Frederik, 2016: 125): "Perikles'in dönemi, Atinalıların girdikleri muharebelerden ziyade o dönemde Atina'da yaşayan büyük sanatçılardan dolayı bu kadar bilinmektedir". Büyük Frederik'in bu ifadelerini "Kişi kendinden bilir işi" söylemi ile açıklayabilmek mümkündür. Zira Büyük Frederik'in genel yaklaşımı, Perikles ile belirgin bir biçimde örtüşmektedir. Nitekim her iki devlet adamı da sanatçılara yüksek statü tanımış ve çok sayıda sanatçıyı desteklemiştir. Bu sayede de sanatçıların kalıcı eserler bırakmalarına imkân sağlamışlardır. Büyük Frederik'in kalıcılığa katkı sağlayan bu anlayışı da, uzak görüşlü ve gelecek yönelimli oluşunu destekleri nitelikler ortaya koymaktadır. Bilim, sanat ve edebiyat uğraşılarını faydasız gören ve saygıyla karşılamayan, orduyu üretici olmadığı gibi, üretenlerin üzerinde de apaçık bir yük olarak kabul eden William Morris (Bkz. 2016: 16-17) gibi (üstelik kendisi on dokuzuncu yüzyılın tanınmış romancı ve sanat yazarıdır) düşünenlerin çoğunlukta olduğu bir dönemde Büyük Frederik'in sanata ve düşünceye verdiği değer, onun engin görüşlülüğünü net bir biçimde yansıtmaktadır.

\subsection{Mekanistik Yaklaşımın Yönetim Anlayışına Uyarlanması}

Büyük Frederik'ten çok önceleri Descartes (2019: 120-122), evreni ve özellikle canlı varlıkların mekanik bir işleyişe tabi olduklarını görüşünü savunmuştur. Spinoza ve Leibniz de Descartes'ın mekanistik düşüncelerini takip etmiştir (Akarsu, 1994: 21-23). Büyük Frederik'in çağdaşı olan Voltaire'in (2018: 177), Mikromegas adlı hikâyesinde; uzmanlık gücü, deneysel çalışmaların zarureti, teknik alet ve makineler geliştirmenin önemini ifade etmekte, bilim ve tekniğin değeri vurgulanmaktadır. Voltaire, bu hikâyesini Büyük Frederik'e göndermiş ve onun beğenisini kazanmıştır. Büyük Frederik'in hikâyeyi beğenmesi, elbette ki kendi mekanistik anlayışına yakın bir görüşün ortaya konmasından ileri gelmektedir. Hatta insan fizyolojisine ilişkin mekanistik görüşü en uç noktalara taşıyan Fransız düşünür Mettrie'nin (1985: 7-13) insan Bir Makina adlı kitabına "Julien Offray de la Mettrie Üzerine" başlıklı yazı ile birebir destekleyen yine Büyük Frederik olmuştur.

Descartes ile başlayan mekanistik dünya görüşünü, yönetim bilimi için özgün kılan husus, bu düşüncenin, Spinoza, Leibniz, Mettrie, Voltaire ve Büyük frerdik gibi filozof ve uygulayıcıları değil, Taylor ve onun takipçilerini de etkilemiş olmasından kaynaklanmaktadır. Yönetim bilimi açısından klasik yönetim anlayışına temel teşkil eden bu görüş, epistemolojik açıdan, stratejik yönetimdeki pozisyon okulunun görüşüne tekabül etmektedir. Zira yönetim bilimindeki mekanik okul ile insan ilişkileri okulunun materyalist-idealist felsefe ayrımı bağlamındaki karşılığı, stratejik yönetimde pozisyon ekolü ile kaynaklara dayalı ekol ekseninde biçimlenmektedir. Netice itibariyle Büyük Frederik, düşünce yapısı ve uygulamaları bakımından stratejik yönetim açısından ağılıklı olarak pozisyon ekolü safına yakın durmaktadır. 
"Friedrich der Grosse" (Büyük Frederik) lakaplı Frederik II zamanında Prusya, en zengin dönemini yaşamış ve görkemli zaferler kazanmıştır. Büyük Frederik, aydınlanmanın tüm değer ve ilkelerini Prusya'da yaşama geçirmeye çalışmış ve belirgin oranda başarılı olmuştur. Prusya ruhunun en temel nitelikleri şunlardır: Rasyonel bir yaşama biçimi ve Tanrı'dan sonra en yüce değere, "devlet"e mutlak boyun eğiş (Tuğcu, 2011: 16-17). Büyük Fredrik'in burada açıklanan yönü, askeri disiplindeki "mutlak itaat" anlayışını desteklemekte, mekanistik dünya görüşünü belirgin bir biçimde yansıtmaktadır. Büyük Frederik'i askeri bir deha olarak nitelendiren Guillaume (2011: 11), despotluk derecesine varan aşırı disiplinli tavrını öne çıkarmakta, yöneticilerin ancak yürütme organını tümüyle kontrol altında tutmaları durumunda görevlerini aksatmadan yerine getirebileceği inancına vurgu yapmaktadır.

McNeill (2005: 557-558) ise Büyük Frederik'i Prusya militarizminin etkin bir uygulayıcısı olarak ifade etmektedir. Büyük Frederik, umut vermeyen kumlu topraklarını ve sınırlı maden kaynaklarını geliştirmekte başarılı olmuş, Prusya'ya egemen olan bir kışla havası oluşturmuştur. Bu açıdan değerlendirildiğinde Büyük Frederik, stratejik yönetimdeki pozisyon ekolünün görüşüne yakınsamakta, hem örgütün hem de piyasanın ancak ve ancak baskın yönetsel bir karakterle etkin bir biçimde kontrol altında tutulabileceği görüşüne dayanmaktadır. Bu bakımdan Büyük Frederik'in, örgüt içinde otoriter, örgüt dışında ise "görünen el" olma anlayışını benimsediği anlaşılabilmektedir.

Orduya talim kavramının getirilmesi, daha sonraki yıllarda Sanayi Devrimi'nin fabrikalarındaki düzenli ve disiplinli işgücü gereksinimini karşılamaya katkıda bulunmuştur. Bu gelişmeler, toplum üzerinde daha kapsamlı bir kontrolü içinde barındırmaya başlamıştır. Bunlar; yeni yargı sistemleri, yeni düzenlemeler ve kamu hayatının pek çok yönünün tertip edilme girişimleri şeklinde kendini göstermiştir (Strathern, 2016: 88-89). Büyük Frederik'in askeri disiplin anlayışındaki düzen, disiplin ve mutlak itaat anlayışı, kendisinden kısa bir süre sonra başlayan Sanayi Devrimi için gerekli işçi ordusunun ön talim işlevi görmüştür. İşlerin en küçük parçasına ayrılması anlayışı, makine gibi işleyen bir askeri düzeni çağrıştırmaktadır. Rus yazar Gorki (2020: 13), Büyük Frederik'in bu yönünü ifade eden şu sözünü nakletmektedir: "Dilediğini düşün ama buyruklara uy." Taylor ve Ford yirminci yüzyılın başında çalışma içeriklerini olabildiğince küçük ve iddiasız tutmayı ve böylece olabildiğince yüksek iş hızları elde etmeyi savunuyorlardı. Zira düşünce ile davranışın birbirinden bu ayrışmasının sonuçları, çok daha önceleri kanıtlanmıştı (Mesnaric, 2011: 31). Büyük Frederik, düşünce özgürlüğünün değil, kurallara uymamanın asıl toplumsal zararı ortaya çıkardığı görüşünü ortaya koymuştur. İnsanların, düşünce ufkunun gelişmesinden yana olan bir yaklaşım sergilemiştir. Taylorist ve Fordist anlayış da bu düşünsel ve toplumsal altyapıdan alabildiğince istifade etmeyi amaçlamıştır. Büyük Frederik, yalnızca mekanistik görüşü benimseyerek tektipleştirici modernizm anlayışa hizmet etmemiştir. Tek yönlü bir uygulayıcıdan ibaret olmayan Büyük Frederik, zamanının çok ilerisindeki görüşleri sayesinde modernizm sonrası (postmodern) anlayışlara da hitap edecek görüşler ileri sürmüştür. Nitekim stratejik yönetim anlayışı da postmodern yönetim yaklaşımları arasında yer almaktadır.

Büyük Frederik, her işe koşmayı ve canla başla çalışmayı hükümdarlığı boyunca sürdürmüştür. Prusya mutlakyönetimini bütünüyle askeri bir yönetim şeklinde tasarlamıştır. Modern Almanya'nın temel niteliklerinden birini teşkil eden düzen ve disiplin anlayışının kaynağı, Prusya'nın düzenli ve disiplinli yönetiminden gelmektedir (Timuçin, 1997: 391). Günümüz literatüründe "Örgütsel vatandaşlık" olarak ifade edilen bu davranış biçimi, köken olarak "iyi asker sendromu" kavramına dayanmaktadır. İyi asker sendromu, verilen görevleri zamanında tamamlamayı, diğerlerine yardım etmeyi ve gönüllü olmayı ifade etmektedir. Kant (2015: 337), Büyük Frederik'in bu yönünü şu sözlerle ifade etmektedir: "Kendisinin hiç olmazsa devletin yalnızca en büyük hizmetkârı olduğunu söylemesi bu anlayışın ifadesidir." Kamu yönetiminin kurucusu Wilson (2018: 55) da sert ve buyurgan hâkimiyetine rağmen Büyük Frederik'in, samimiyetle kendisini devletin bir numaralı hizmetkârı sayması ve yüksek makamına kamunun bir emaneti gözüyle bakmasından övgüyle bahsetmektedir. 
Büyük Frederik'e göre insanoğlu, sanıldığından çok daha fazla makine olmaya elverişlidir. Bu mümkün olduğu ölçüde, düşüncenin yerine alışkanlığı koymak gerekmektedir (Bouthoul, 1997: 117). Büyük Frederik'in yapılandırdığı ordu, mekanik örgütlenme açısından tam bir prototip olarak ortaya çıkmıştır. Karşılaşılan böylesi bir yeni yapılanma, yönetim alanında çok öğretici olmuştur. Roma birliklerinden esinlenerek gerçekleştirilen reformlarda, yenilenmiş Avrupa ordularının deneyiminden de faydalanılmıştır. Büyük Frederik, yalnızca taklide dayanan bir reform gerçekleştirmemiş, aynı zamanda kendi buluşu olan yenilikleri de hayata geçirmiştir. Söz konusu yeniliklerde elbette ki yaşadığı dönemin mekanik icatlarından faydalanmıştır (Morgan, 1998: 28). Büyük Frederik (2016: 84), stratejik yönetimde zamanlamaya dayalı strateji tipolojilerinde "öncü" ve "taklitçi" gibi zıtlıklarla ifade edilen hususu kendi açısından şu şekilde ifade etmektedir: "Eski olan ille de iyi değildir, bilhassa abartıldığında. Büyük insanlar, kabul ediyorum hataları ve zaafları vardı. Gelin, onları yaptıkları küçük şeylerde değil, büyük işlerde taklit edelim."

Etkin bir makine düzeni içinde yer alan bireylerden oluşan bir yapı öngören ve bu doğrultuda çalışmalar yürüten Büyük Frederik, söz konusu yönüyle övgülerin yanı sıra eleştirilerden de nasibini almıştır. Nitekim Nietzsche (2020: 50-54), makine düzeni gibi işleyen Alman toplum yapısını olumlu karşılamamaktadır. Çünkü Nietzsche'ye göre, Büyük Frederik'ten başlayıp devam eden süreçte Almanlar, ortalama bireyler haline gelmiştir. Nietzsche'nin benimsemiş olduğu "üstün insan" anlayışı ile uyuşmadığı için, böylesi bir mekanik toplum düzeninde yer alan bireyleri "ortalama" nitelendirmesiyle, kendine göre bir nevi olumsuz eleştiri getirmektedir. Oysa Nietzsche'nin "üstün insan” görüşü, başlı başına birçok olumsuzluğu içinde barındırdığı için, böylesi bir olumsuz görüşten hareketle getirilen eleştiri de yeterince sağlıklı sonuçlar ortaya koymamaktadır. Konuya Alman (Prusya) toplumu dışından bakıldığında daha isabetli çıkarımlarda bulunabilmek mümkün görünmektedir. Örneğin, düzene kavuşan Prusya'nın güç ve etkinliğini (komşu ülkelere, özellikle de Fransa'ya karşı) sürekli bir biçimde artırması, Fransız yazar Daudet'nin (1998) eserlerinde çok net bir biçimde varlığını hissettirmektedir.

Bilimsel yönetimin kurucusu Taylor'un klasik yönetim anlayışı, işyerlerinde olağanüstü etkiler meydana getirmiştir. Taylorist anlayışla birlikte vasıflı zanaatkârların, yerlerini vasıfsız işçilere bırakma süreci hızlanmıştır. Buna karşın, üretkenlik, belirgin ölçülerde artış göstermiştir. Çok yerilmesine rağmen bu süreç çok büyük etkiler doğuruştur. Üretkenlikteki artışlar, Taylor'dan yaklaşık bir buçuk asır önce Büyük Frederik'in askeri birimlerinde gerçekleştirdiği ordu reformlarına benzer biçimde birtakım insani bedeller ödenerek sağlanabilmiş, çok sayıdaki iş̧̧i robota dönüştürülmüştür (Morgan, 1998: 36-37). Dolayısıyla Büyük Frederik'in merkeze aldığı dünya görüşünü yalnızca makineleşme, otomasyon ve yapay zekâ uygulaması şeklindeki sürecin başlangıç tohumlarını atan ve insanlığa salt olumlu kazanımlar sağlaması şeklinde izah etmeye çalışmak çok da doğru görünmemektedir. Bir görüş ne yoğun kesif biçimde ifade ediliyorsa, karşıt görüşün de aynı yoğunlukta dile getirilebileceği, evrensel bir gerçeklik olarak bilinmektedir. Dolayısıyla bu makalede salt Büyük Frederik'i “övündüklerimiz" tablosu içinde ele almak amaçlanmamaktadır. Zira (bu makalenin odak konusu olmamasına rağmen) Büyük Frederik'in "dövündüklerimiz" tablosu içinde yer alan yönlerinin de bulunduğunu ifade etmek gerekmektedir. Nitekim yukarıdaki anlatımda Morgan, "ödenen insani bedeller" konusuna kısaca değinmiştir. Bunun çok daha fazlası, mekanikleşen toplum yapısının olumsuz etkilerini bizzat hisseden ve endişelenen filozoflar tarafından dile getirilmiştir (Chaix-Ruy, 2001: 184). Benzer türden endişeler, çok sayıdaki sosyalist ve diğer farklı görüşlere sahip düşünür ve yazarlar tarafından kaleme alınmıştır. Bütün bu düşünür ve yazarların öncülüğünü ise Fransız Ansiklopedistler olan Diderot ve D'alembert yapmıştır. Ansiklopedistlerin sonrasında Beckmann, Voltaire, Simon, Fourier, Proudhon, Butler, Zamyatin, Bellamy ve Wells gibi düşünür ve yazarlar, mekanik örgüt yapısıyla ön plana çıkan teknokratik ütopyalar/distopyalar kaleme alarak, mekanistik bakış açısına kapsamlı eleştiriler yöneltmişlerdir.

\section{Sonuç}


Fransız düşünür d'Alambert'e (2016: 18) göre, farklı bakış açıları, bazı konuları aydınlatan bir ışık gibi işlev üstlenmektedir. Bu makalede, tarihte özgün bir yere sahip bulunan Büyük Frederik'in yönetsel faaliyetlerine, stratejik yönetim bakış açısıyla odaklanıldığı için, d'Alambert'in vurguladığı türden bir aydınlatıcı rol üstlenilmeye çalışılmıştır. Literatür incelemesinde öncül çalışmalara rastlanmamış olması nedeniyle de bu makalede, keşifsel bir düzeyin ötesine geçilememiştir. Bir başka Fransız düşünür olan Sartre (2017: 72), belirli bireylerin olumlu kazanım olarak ortaya koyduklarından faydalanarak, insanlığa katkı sunan edinimler sağlanabileceğini ifade etmektedir. Bu makalede, Büyük Frederik'in yönetsel faaliyetlerine dönük çalışma yürütülmesinin temel nedeni, Sartre tarafından dile getirilen husus ile belirgin bir uyum sergilemektedir.

Makalenin araştırma sorusu, "Büyük Frederik'in gerçekleştirdiği yönetsel faaliyetler, zamanının ötesine geçerek çağdaş yönetim alanına anlamlı katkılar sağlayabilecek uygulamaları barındırmakta mıdır?" şeklinde ifade edilmiştir. Birçok geçmiş dönem yöneticisi, arkasında herhangi kayda değer bir yönetsel anlayış ya da uygulama bırakmamış, bazı istisnai yöneticiler ise bu konuda oldukça cömert davranmışlardır. Büyük Frederik, öncelikle hayata geçirdiği yönetsel uygulamalarıyla, bunun yanı sıra, sözlü ve yazılı görüşleriyle de günümüz bilimsel çalışmalarına katkı sağlayabilecek nitelikleri arkasında kapsamlı bir miras olarak bırakmıştır. Bu nedenledir ki Büyük Frederik'in yaklaşık iki yüz elli yıl önceki düşünce ve uygulamalarının etkileri günümüze kadar yansıyabilmiştir. Buradan hareketle, Büyük Frederik'e ilişkin çok sayıda yazılı kaynak bulunduğu için, yönetim başta olmak üzere farklı pek çok alanda çalışma yapılabileceği sonucu açıkça ortaya çıkmaktadır.

Stratejik yönetimi, üç temel bileşen şeklinde ifade edebilmek mümkündür. Bu bileşenlerden birincisi uzun vadeli örgütsel amaçlara sahip olmayı ifade etmektedir. Bileşenlerin ikincisi, söz konusu uzun vadeli örgütsel amaçlara taşıyabilecek uygun nitelikteki iş yapma biçimlerini belirlemeyi ifade etmektedir. Bileşenlerin üçüncüsü ise belirlenen eylemler için gerekli kaynakları edinmeye çalışmayı ifade etmektedir. Söz konusu üç temel unsuru dengeli bir biçimde yürütmeyi başarmış bir yönetici olan Büyük Frederik, bu makalenin yazım hacmi sınırları nedeniyle ancak belirli ölçülerde (analiz başlıkları bağlamında) ele alınabilmiştir. Büyük Frederik'in gerçekleştirmiş olduğu kapsamlı yönetsel faaliyetler göz önünde bulundurulduğunda söz konusu faaliyetlerin, stratejik yönetimin yanı sıra kamu ya da işletme yönetiminin diğer alt alanlarına (örgütsel davranış, durumsallık yaklaşımı, sistem yaklaşımı gibi) konu olabileceği sonucu ortaya çıkmaktadır. Örneğin durumsallık yaklaşımına (Büyük Fredrik: 2016: 73; 98), klasik yönetim anlayışındaki düzen, disiplin ve işbölümü gibi ilkelere (Büyük Fredrik: 2016: 74-75; 124; 129; 150) ilişkin, birincil ve ikinci kaynaklardan edinilebilecek analiz unsurlarına ulaşmak mümkün görünmektedir. Ayrıca stratejik yönetim süreci; strateji belirleme, gerekli analizlerin yapılması, yapılandırma, uygulama ve kontrol gibi alt unsurlardan oluştuğu için gelecek çalışmalarda, söz konusu süreçler kapsamındaki incelemelerin, Büyük Frederik ya da belirlenecek olan herhangi bir tarihi şahsiyete (fenomene) ilişkin olarak yürütülmesi olası görünmektedir.

Hakem Değerlendirmesi: Dış bağımsız.

Çıkar Çatışması: Yazar çıkar çatışması bildirmemiştir.

Finansal Destek: Yazar bu çalışma için finansal destek almadığını beyan etmiştir.

\section{Kaynakça}

Akad, M. T. (2003). Strateji Üzerine. İstanbul: Kastaş Yayınları.

Akarsu, B. (1994). Çağdaş Felsefe Kant'tan Günümüze Felsefe Akımları. İstanbul: İnkılap Kitabevi.

Bebel, A. (2019). Hz. Muhammed ve Arap-İslam Kültürü Dönemi. Çev. Veysel Atayman, İstanbul: Bordo Siyah Yayınları. 
Bouthoul, G. (1997). Politika Sanatı. Çev. Sabahattin Eyüboğlu ve Vedat Günyol, İstanbul: Cem Yayınevi. Büyük Frederik (2016). Anti-Makyavel Nikola Makyavel'in "Prens" Adlı Eserine Dair Bir Eleştiri Denemesi. Çev. Nilüfer Epçeli, İstanbul: Yeditepe Yayınevi.

Carlyle, T. (1990). History of Friedrich II of Prussia, called Frederick The Great. London: Elibron.

Chaix-Ruy, J. (2001). Nietzsche Yaşamı ve Felsefesi. Çev. N. Berna Serveryan, İstanbul: Çiviyazıları Yayıncılık. Clausewıtz, C. v. (1999). Savaş Üzerine. Çev. H. Fahri Çeliker, İstanbul: Özne Yayınları.

d'Alambert, J. I. R. (2018). Felsefenin Öğeleri ya da insan Bilgilerinin IIkeleri Üstüne Deneme. Çev. Hüseyin Köse, Ankara: Pharmakon Yayınevi.

Daudet, A. (1998). Pazartesi Öyküleri I. Çev. Sabri Esat Siyavuşgil, Çağdaş Matbaacılık Yayıncılık.

Descartes, R. (2019). Ruhun Tutkuları. Çev. Murat Erşen, İstanbul: Say Yayınları.

Dilthey, W. (2004). Alman Ruh Tarihine Dair Tetkikler. Çev. Hasan Cemil, İstanbul: Yeni Zamanlar Yayınları.

Dorn, W. L. (1931). The Prussian Bureaucracy in the Eighteenth Century, Political Science Quarterly, V.46, N.3, pp. 403-423.

Duffy, C. (1985). Frederick the Great: A Military Life. New York: Routledge.

Geiger, M. (2015). Estetik Anlayış. Çev. Tomris Mengüşoğlu, Ankara: Doğu Batı Yayınları.

Glendinning, S. (2014). Derrida. Çev. Nursu Örge, Ankara: Dost Kitabevi.

Gorki, M. (2020). Tolstoy'dan Anılar. Çev. Akşit Göktürk, İstanbul: Yapı Kredi Yayınları.

Gülboy, B. (2015). Redefining the First World War within the Context of Clausewitz's "Absolute War" Dystopia, Perception, V.XX, N.2-3, pp. 7-22.

Hegel, G. W. F. (2011a). Tarih Felsefesi - 1. Çev: Aziz Yardımlı, İstanbul: İdea Yayınevi.

Hegel, G. W. F. (2011b). Tarih Felsefesi - 4. Çev: Aziz Yardımlı, İstanbul: İdea Yayınevi.

Kant, I. (2015). Seçilmiş Yazılar. Çev. Nejat Bozkurt, İstanbul: Sentez Yayıncılık.

Karabulut, A. ve Değer, F. (2015). Uluslararası İlişkilerde Güvenlik Kavramı ve Realist Yaklaşım’a Genel Bakış, İstanbul Gelişim Üniversitesi Sosyal Bilimler Dergisi, C.2, S.2.

Karaosmanoğlu, A. L. (2007). Muhteşem Ortaklık: Kant ve Clausewitz, Uluslararası Iliş̧kiler, C.4, S.14, s.161183.

Kılıç, T. (2019). Güncel Yönetim Paradigmaları. İstanbul: AZ Yayıncılık.

King, J. E. (1977). On Clausewitz: Master Theorist of War. Naval War Collage Review, V.30, N.2, pp. 3-36.

McNeill, W. H. (2005). Dünya Tarihi. Çev. Alaeddin Şenel, Ankara: İmge Kitabevi.

Mesnaric, C. (2011). Yöneticiler İçin Aristoteles. Çev. E. Kayaoğlu, İstanbul: Sistem Yayıncılık.

Mettrie, J. O. d. L. (1985). Insan Bir Makina. Çev. Zehra Bayramoğlu, İstanbul: Süreç Yayıncılık.

Morgan, G. (1998). Örgüt ve Yönetim Teorilerinde Metafor. Çev. Gündüz Bulut, İstanbul: MESS Yayınları.

Morris, W. (2016). Faydalı Işler Faydasız Uğraşlar. Çev. Murat Can Mutlu, 1984 Yayınevi, İstanbul.

Musashi, M. (2015). Beş Çember Kitabı. Çev. Sibel Özbudun, İstanbul: Altın Kitaplar Yayınevi.

Nietzsche, F. (2020). Putların Alacakaranlığı. Çev. Mustafa Tüzel, İstanbul: Türkiye İş Bankası Kültür Yayınları. 
Oetinger, V. B., Ghyczy, V. T. ve Bassford, C. (Ed.). (2002). Clausewitz ve Strateji. Çev. Zülfü Dicleli, İstanbul: Türk Henkel Dergisi Yayınları.

Özlem, D. (2019). Hermeneutik ve Şiir. İstanbul: Notus Kitap Yayıncılık.

Plotinus (2021). Plotinus'un Eksiksiz Külliyatı. Çev. Ahmet Ceylan, İstanbul: Gece Kitaplığı.

Rifat, M. (2020). Sait Faik'i Yorumlayanlar Eleştirinin Eleştirisi. İstanbul, Yapı Kredi Yayınları.

Ritter, G. (1974). Frederick the Great: A Historical Profile, University of California Press.

Sartre, J-P. (2017). Varoluşçuluk. Çev. Asım Bezirci, İstanbul: Say Yayınları.

Schieder, T. (2000). Frederick the Great. Translated and edited by Sabina Berkeley and H. M. Scott. New York: Longman.

Showalter, D. E. (1996). The Wars of Frederick the Great. London: Longman.

Störig, H. J. (2013). Vedalardan Tractatus'a Dünya Felsefe Tarihi. Çev. Nilüper Epçeli, İstanbul: Say Yayınları.

Strathern, P. (2016). 90 Dakikada Foucault. Çev. Dilara Dilmen, İstanbul: Zeplin Kitap.

Sun Tzu. (1996). Savaş Sanatı. Çev. Sibel Özbudun ve Zeynep Ataman, İstanbul: Altın Kitaplar Yayınevi.

Timuçin, A. (1997). Düşünce Tarihi. İstanbul: İnsancıl Yayınları.

Topdemir, H. G. (2008). Ibn El-Heysem ve Yeni Optik. Ankara: Lotus Yayınevi.

Tuğcu, T. (2001). Immanuel Kant ve Transendental Idealizm. Ankara: Alesta Yayınları.

Waldron, A. ve Huang, J.H. (2018). Sun Tzu: The New Translation of the Art of War, Naval War College Review, Vol.47, N.4.

Wei, Q. (2017). Chinese Culture Teaching for English Majors - A Case Study of Sun Tzu Culture, Theory and Practice in Language Studies, Vol.7, No.3, pp. 209-218.

Wilson, R. (2018). Sun Tzu and the Art of Cyberwar, Defence AT\&L, Vol.47, Is.1.

Wilson, W. (2018). Idarenin Incelenmesi. Çev. Nur Şat, Ankara: Librete Yayınları.

Voltaire, (2018). Candide ya da Iyimserlik ve Micromegas. Çev. S. İpek Ortaer Montanari, İstanbul: İthaki Yayınları.

Yılmaz, M. L. (2009). Illk 500'de Faaliyet Gösteren Konya'daki İşletmelerin Stratejik Yönetime Bakış Açıları, Sorunları ve Çözüm Önerileri, Sosyal Ekonomik Araştırmalar Dergisi, 8 (16), 159-178. 